\title{
ANALISIS KADAR PROFIL LIPID PADA PASIEN YANG MENGALAMI STROKE DAN PJK DI RSUD BUDHI ASIH
}

\author{
Azwan Nurdin ${ }^{1)}, *$ Cut Ervinar Yari $^{1)}$, Sungkono ${ }^{1)}$ \\ ${ }^{1}$ Program Studi Analis Kesehatan, Fakultas Kesehatan, Universitas Mohammad Husni Thamrin \\ Correspondence author: Cut Ervinar Yari, andrew_margareth@yahoo.com, Jakarta, Indonesia
}

\begin{abstract}
ABSTRAK
Peningkatan taraf hidup serta perubahan pola makan yang kurang baik, merokok, diet yang kurang sehat, kurangnya aktifitas fisik, komsumsi alkohol dapat mejadi faktor risiko pada obesitas, hipertensi, kolesterol tinggi, diabetes millitus, stroke dan penyakit jantung koroner. Berdasarkan hasil Riskesdas tahun 2013 menunjukkan adanya peningkatan prevalensi stroke per 100.000 di Indonesia. Tujuan penelitian ini untuk mengetahui perbandingan kadar profil lipid pada stroke dan PJK. Metode Penelitian merupakan penelitian observasional analitik dengan pendekatan cross sectional. Menggunakan data sekunder dengan mengambil data rekam medis pasien RSUD Budhi Asih periode Juli 2018 - Juli 2019. Data rekam medis yang diambil adalah kadar profil lipid 50 pasien Stroke dan 50 pasien PJK. Kemudian data diolah menggunakan SPSS Uji T Independens. Berdasarkan hasil persentase yang telah dilakukan dari pemeriksaan profil lipid pada pasien yang mengalami stroke, didapatkan kadar kolesterol total abnomal $56 \%$, kadar HDL kolesterol abnormal 10\%, kadar LDL kolesterol abnormal 80\% dan kadar trigliserida abnormal 32\%. Mengalami PJK didapatkan kadar kolesterol total abnomal 60\%, kadar HDL kolesterol abnormal 12\%, kadar LDL kolesterol abnormal 84\% dan kadar trigliserida abnormal 36\%. Dan setelah melakukan analisa data dengan SPSS Uji $\mathrm{T}$ independens didapatkan nilai p-value kadar kolesterol 0303, kadar HDL 0.745, kadar LDL 0,635 dan trigliserida 0.30. Dengan ketentuan p-value $<0.005$ maka, ada perbedaan profil lipid pasien yang mengalami stroke dengan PJK.

Kata kunci : : Profil lipid, PJK, Stroke.
\end{abstract}

\begin{abstract}
Increased living standards and changes in poor diet, smoking, unhealthy diets, lack of physical activity, alcohol consumption can be risk factors for obesity, hypertension, high cholesterol, diabetes millitus, stroke and coronary heart disease. Based on the results of Riskesdas 2013, it shows an increase in the prevalence of stroke per 100,000 in Indonesia. The purpose of this study was to determine the comparison of lipid profile levels in stroke and CHD. The research method is an analytic observational study with a cross sectional approach. Using secondary data by taking medical record data of Budhi Asih Hospital patients for the period July 2018 - July 2019. The medical record data taken was the lipid profile levels of 50 stroke patients and 50 CHD patients. Then the data is processed using the SPSS Independent T Test. Based on the percentage results that have been carried out from examining lipid profiles in patients who have had a stroke, it was found that the abnormal total cholesterol level was $56 \%, 10 \%$ abnormal HDL cholesterol level, $80 \%$ abnormal LDL cholesterol level and 32\% abnormal triglyceride levels. Having CHD was found to have an abnormal total cholesterol level of $60 \%$, an abnormal HDL cholesterol level of $12 \%$, an abnormal LDL cholesterol level of $84 \%$ and an abnormal triglyceride level of $36 \%$. And after analyzing the data with the SPSS independent T test, the p-value of cholesterol levels was 0303, HDL levels were 0.745 , LDL levels were 0.635 and triglycerides were 0.30 . With the provision of $\mathrm{p}$-value $<0.005$, there are differences in the lipid profiles of patients who have had a stroke with CHD.
\end{abstract}

Key words: Lipid profile, CHD, Stroke.

Open Journal System (OJS): journal.thamrin.ac.id

http://journal.thamrin.ac.id/index.php/anakes/issue/view/35 


\section{PENDAHULUAN}

Stroke merupakan penyebab kecacatan nomor satu dan penyebab kematian nomor tiga di dunia setelah penyakit jantung dan kanker, baik di negara maju maupun berkembang. Data penelitian di Amerika tahun 2011 menemukan angka insiden 795.000, prevalensi 2.980 .000 dan mortalitas 150.000 per tahun (Roger VL,2011 dalam Kemenkes RI, 2013).

Sementara di Indonesia berdasarkan hasil Riset Kesehatan Dasar (Riskesdas) tahun 2007 stroke merupakan penyebab kematian pada semua kelompok umur tertinggi dengan porporsi $15,4 \%$, sedangkan kelompok umur 55-64 tahun mencapai 26,8\%, baik perkotaan maupun pedesaan dan kasus stroke termuda ditemukan pada kelompok umur 18-24 tahun. Prevalensi stroke di Indonesia sebesar 830 per 100.000 penduduk dan telah didiagnosa oleh tenaga kesehatan adalah 600 per 100.000 penduduk. NAD merupakan provinsi dengan prevalensi stroke tertinggi, yaitu sebesar 16,6\% dan terendah di Papua $(3,8 \%)$ (Kemenkes RI, 2013).

Berdasarkan hasil Riskesdas tahun 2013 menunjukan adanya peningkatan prevalensi stroke per 100.000 di Indonesia, yaitu 830 pada tahun 2007 meningkat menjadi 1.210 pada tahun 2013.

Peningkatan taraf hidup serta perubahan pola makan yang kurang baik, merokok, diet yang kurang sehat, kurangnya aktifitas fisik, komsumsi alkohol dapat mejadi faktor risiko pada obesitas, hipertensi, kolesterol tinggi, diabetes millitus, penyakit jantung koroner. Pola makan yang kurang baik seperti mengkomsumsi makanan yang banyak mengandung lemak dapat menjadi penyebab penumpukan lemak di dalam tubuh sehingga dapat menyebabkan obesitas. Obesitas semakin menyebar pada masyarakat modern, terutama pada mereka yang mengkonsumsi banyak karbohidrat dan lemak, dan tidak hanya terbatas pada populasi yang makmur, namun juga memenuhi populasi dimana makanan cepat saji berharga murah tersebar luas. Obesitas terkait dengan beberapa gangguan kardiovaskular dan metabolik yang mengancam jiwa, termasuk penyakit tromboemboli dan diabetes melitus. (Greestein,B. dan Wood, D.F., 2010 : 97)

Pada penyakit arteri koroner atau Penyakit Jantung Koroner (PJK) adalah istilah yang mengacu pada penyakit jantung, penyakit yang selama beberapa dekade telah menjadi penyebab utama kematian pria dan wanita di Amerika Serikat. Serangan jantung tercatat sebanyak 46\% terjadi di negara-negara barat. Di Amerika Serikat setiap tahunnya sekitar 1,5 juta orang mengalami serangan jantung dan terjadi 500.000 kasus kematian. (Durstine, J.L., 2012:13)

Berdasarkan hasil Survei Kesehatan Rumah Tangga Nasional (SKRTN) tahun 2001, dalam 10 tahun terakhir angka kematian PJK mengalami peningkatan. Pada tahun 1991, angka kematian akibat Penyakit Jantung Koroner (PJK) adalah 16\%. Tercatat angka kematian PJK pada tahun 1995 sebesar 19,0\%, tahun 1998 menjadi 24,4\%, dan tahun 2001 meningkat 24,6\%. atau diperkirakan angkanya mencapai 53,5 per 100.000 penduduk Indonesia. (Depkes RI, 2012) 
Penyebab munculnya perubahan tekanan darah dapat disebabkan oleh pengendapan kolesterol dan lipid (aterosklerosis) yang dapat menyebabkan tekanan darah semakin tinggi sehingga beresiko terkena penyakit jantung koroner. Pola makan tidak sehat dengan tidak memperhatikan menu sehat dengan gizi seimbang cenderung memicu penumpukan lemak dan kolesterol dalam pembuluh darah (Ridwan, 2013)

Cardiovascular disease dapat disebabkan oleh berbagai macam hal. Salah satunya dikarenakan oleh dislipidemia, dan dari 9,4 juta kematian setiap tahun $51 \%$ disebabkan oleh karena stroke, dan $45 \%$ disebabkan karena coronary heart disease. (Data WHO, 2013)

Pada dasarnya tingginya kadar kolesterol bukan penyebab utama mortalitas seseorang.Tidak banyak data yang menyatakan bahwa tingginya kadar kolesterol dapat secara langsung menyebabkan kematian pada seseorang, namun kadar kolesterol yang tinggi ternyata merupakan etiologi yang sering menyebabkan terjadinya aterosklerosis, Stroke, serta cardiovascular disease (Hananta, 2011)

\section{METODE}

Karena keterbatasan waktu dan tempat maka Populasi penelitian adalah data rekam medis pada RSUD Budhi Asih, Jakarta Timur. Sampel peneltian adalah data rekam medis hasil pemeriksaan profil lipid pasien yang mengalami stroke dan Penyakit Jantung Koroner (PJK) pada RSUD Budhi Asih, Jakarta Timur periode Juli 2018- Juli 2019. Metode penelitian ini dilakukan secara deskriptif kualitatif dengan cara pengumpulan data sekunder dari RSUD Bhudi Asih, Jakarta timur. Dalam penelitian ini, data stroke dan Penyakit Jantung Koroner (PJK) dapat dilihat pada diagnosa pasien di rekam medis. Untuk data pemeriksaan profil lipid dapat diperoleh dari data laboratorium. Data diambil dari pasien yang mengalami stroke dan Penyakit Jantung Koroner (PJK) dan yang melakukan pemeriksaan profil lipid. Data-data yang telah diperoleh pada penelitian ini diolah menggunakan SPSS, Uji T Idenpendens.

\section{HASIL \& PEMBAHASAN}

Berdasarkan data hasil pemeriksaan kadar profil lipid pada pasien yang mengalami Stroke dan PJK di RSUD Budhi Asih, Jakarta Timur diperoleh hasil sebagai berikut: 
Tabel 1

Persentase hasil pemeriksaan Profil lipid pada 50 pasien yang mengalami Stroke dan 50 Pasien PJK pada RSUD Budhi Asih

1.1 Stroke

\begin{tabular}{rcccc}
\hline \multicolumn{5}{c}{ Jumlah Pasien ( persentase ) } \\
\hline & Kolesterol & PDofil Lipid \\
$\mathrm{n}(\%)$ & $\mathrm{n}(\%)$ & $\begin{array}{c}\text { LDL } \\
\mathrm{n}(\%)\end{array}$ & $\begin{array}{c}\text { Trigliserida } \\
\mathrm{n}(\%)\end{array}$ \\
\hline Normal & $22(44)$ & $45(90)$ & $10(20)$ & $34(68)$ \\
\hline Abnormal & $28(56)$ & $5(10)$ & $40(80)$ & $16(32)$ \\
\hline Total & $50(100)$ & $50(100)$ & $50(100)$ & $50(100)$ \\
\hline
\end{tabular}

$1.2 \mathrm{PJK}$

\begin{tabular}{ccccc}
\hline \multicolumn{5}{c}{ Jumlah Pasien (persentase ) } \\
\hline & \multicolumn{4}{c}{ Profil Lipid } \\
\hline Kolesterol & $\begin{array}{c}\text { HDL } \\
\mathrm{n}(\%)\end{array}$ & $\begin{array}{c}\text { LDL } \\
\mathrm{n}(\%)\end{array}$ & $\begin{array}{c}\text { Trigliserida } \\
\mathrm{n}(\%)\end{array}$ \\
\hline Normal & $20(40)$ & $44(88)$ & $8(16)$ & $32(64)$ \\
\hline Abnormal & $30(60)$ & $6(12)$ & $42(84)$ & $18(36)$ \\
\hline Total & $50(100)$ & $50(100)$ & $50(100)$ & $50(100)$ \\
\hline
\end{tabular}

(Sumber : Data RSUD Budhi Asih, 2019)

Berdasarkan hasil pada tabel 1 didapatkan persentase kadar profil lipid pada 50 pasien yang mengalami stroke yaitu, kadar kolesterol total normal sebanyak 44\% (22 orang) dan abnomal 56\% (28 orang), kadar HDL kolesterol normal sebanyak 90\% (45 orang) dan abnormal 10\% (5 orang), kadar LDL kolesterol normal sebanyak 20\% (10 orang) dan abnormal 80\% (40 orang), dan kadar trigliserida normal sebanyak $68 \%$ (34 orang) dan abnormal 32\% (16 orang).

Berdasarkan hasil pada tabel 1 didapatkan persentase kadar profil lipid pada 50 pasien yang mengalami PJK yaitu, kadar kolesterol total normal sebanyak 40\% (20 orang) dan abnomal 60\% (30 orang), kadar HDL kolesterol normal sebanyak 88\% (44 orang) dan abnormal 12\% (6 orang), kadar LDL kolesterol normal sebanyak 16\% (8 orang) dan abnormal 84\% (4 orang), dan kadar trigliserida normal sebanyak $64 \%$ (32 orang) dan abnormal 36\% (18 orang). 
Tabel 2

Persentase hasil pemeriksaan Profil lipid pada 50 pasien yang mengalami Stroke dan 50 pasien PJK di RSUD Budhi Asih berdasarkan Usia.

2.1 Stroke

\begin{tabular}{|c|c|c|c|c|c|c|c|c|}
\hline \multirow{2}{*}{$\begin{array}{c}\text { Usia } \\
\text { (Tahun) }\end{array}$} & \multicolumn{2}{|c|}{$\begin{array}{c}\text { Kolesterol Total } \\
(\mathrm{mg} / \mathrm{dL})\end{array}$} & \multicolumn{2}{|c|}{$\begin{array}{c}\text { HDL kolesterol } \\
(\mathrm{mg} / \mathrm{dL})\end{array}$} & \multicolumn{2}{|c|}{$\begin{array}{l}\text { LDL kolesterol } \\
(\mathrm{mg} / \mathrm{dL})\end{array}$} & \multicolumn{2}{|c|}{$\begin{array}{c}\text { Trigliserida } \\
\text { (mg/dL) }\end{array}$} \\
\hline & $\begin{array}{c}\text { Normal } \\
\mathrm{n}(\%)\end{array}$ & $\begin{array}{l}\text { Abnorma } \\
\ln (\%)\end{array}$ & $\begin{array}{c}\text { Normal } \\
\mathrm{n}(\%)\end{array}$ & $\begin{array}{c}\text { Abnorma } \\
1 \mathrm{n}(\%)\end{array}$ & $\begin{array}{c}\text { Normal } \\
\mathrm{n}(\%)\end{array}$ & $\begin{array}{c}\text { Abnorma } \\
1 \mathrm{n}(\%)\end{array}$ & $\begin{array}{c}\text { Normal } \\
\mathrm{n}(\%)\end{array}$ & $\begin{array}{c}\text { Abnorma } \\
\ln (\%)\end{array}$ \\
\hline$\leq 50$ & $5(10)$ & $6(12)$ & $8(16)$ & $4(8)$ & $4(8)$ & $8(16)$ & $7(14)$ & $5(10)$ \\
\hline $51-60$ & $11(22)$ & $8(16)$ & $16(32)$ & $4(8)$ & 2(4) & $14(28)$ & $10(20)$ & $6(12)$ \\
\hline $61-70$ & $4(8)$ & $10(20)$ & $8(16)$ & $4(8)$ & $4(8)$ & $13(26)$ & $12(24)$ & $4(8)$ \\
\hline$\geq 70$ & $4(8)$ & $2(4)$ & $5(10)$ & $1(2)$ & 2(4) & $3(6)$ & 2(4) & $4(8)$ \\
\hline Jumlah & $24(48)$ & $26(52)$ & $37(74)$ & $113(26)$ & $12(24)$ & $38(76)$ & $31(62)$ & $19(38)$ \\
\hline \multicolumn{9}{|l|}{ 2.2 PJK } \\
\hline \multirow{2}{*}{$\begin{array}{c}\text { Usia } \\
\text { (Tahun) }\end{array}$} & \multicolumn{2}{|c|}{$\begin{array}{l}\text { Kolesterol Total } \\
(\mathrm{mg} / \mathrm{dL})\end{array}$} & \multicolumn{2}{|c|}{$\begin{array}{l}\text { HDL kolesterol } \\
(\mathrm{mg} / \mathrm{dL})\end{array}$} & \multicolumn{2}{|c|}{$\begin{array}{l}\text { LDL kolesterol } \\
(\mathrm{mg} / \mathrm{dL})\end{array}$} & \multicolumn{2}{|c|}{$\begin{array}{l}\text { Trigliserida } \\
(\mathrm{mg} / \mathrm{dL})\end{array}$} \\
\hline & $\begin{array}{c}\text { Normal } \\
\mathrm{n}(\%)\end{array}$ & $\begin{array}{l}\text { Abnorma } \\
\ln (\%)\end{array}$ & $\begin{array}{c}\text { Normal } \\
\mathrm{n}(\%)\end{array}$ & $\begin{array}{c}\text { Abnorma } \\
1 \mathrm{n}(\%)\end{array}$ & $\begin{array}{c}\text { Normal } \\
\mathrm{n}(\%)\end{array}$ & $\begin{array}{l}\text { Abnorma } \\
\ln (\%)\end{array}$ & $\begin{array}{c}\text { Normal } \\
\mathrm{n}(\%)\end{array}$ & $\begin{array}{c}\text { Abnorma } \\
\ln (\%)\end{array}$ \\
\hline$\leq 50$ & $6(12)$ & $10(20)$ & $9(18)$ & $1(2)$ & $3(6)$ & $10(20)$ & $11(22)$ & $3(6)$ \\
\hline $51-60$ & $3(6))$ & $14(28)$ & $19(38)$ & $1(2)$ & $2(4)$ & $12(48)$ & $1(2)$ & $9(18)$ \\
\hline $61-70$ & $2(4)$ & $5(10)$ & $12(24)$ & $0(0)$ & $0(0)$ & $13(26)$ & $10(20)$ & $1(2)$ \\
\hline$\geq 70$ & $6(12)$ & $4(8)$ & $3(6)$ & $5(10)$ & $4(8)$ & $6(12)$ & $11(22)$ & $4(8)$ \\
\hline Jumlah & $17(34)$ & $33(66)$ & $43(86)$ & $17(14)$ & $9(18)$ & $41(82)$ & $32(64)$ & $18(36)$ \\
\hline
\end{tabular}

(Sumber : Data RSUD Budhi Asih tahun 2019)

Berdasarkan pengelompokan pada tabel 2 dapat dilihat hasil pemeriksaan kadar profil lipid pada 50 pasien berdasarkan kelompok usia yang mengalami stroke (tabel 2.1). Pada pasien berdasarkan kelompok usia $\leq$ 50 tahun persentase kadar kolesterol total normal adalah 10\% dan abnormal 12\%, HDL kolesterol normal 16\% dan abnormal 8\%, LDL kolesterol normal 8\% dan abnormal 16\%, kemudian trigliserida normal 14\% dan abnormal 10\%. Berdasarkan usia 51-60 tahun persentase kadar kolesterol total normal 8\% dan abnormal 16\%, HDL kolesterol normal 16\% dan abnormal 8\%, LDL kolesterol normal 4\% dan abnormal $28 \%$, untuk trigliserida normal 20\% dan abnormal 12\%. Pada usia 61-70 tahun diperoleh hasil persentase kadar kolesterol total normal 22\%, abnormal 20\% dan HDL kolesterol yaitu normal 32\% dan abnormal $8 \%$, LDL kolesterol normal $8 \%$ dan abnormal 26\%, lalu trigriserida normal 24\% dan abnormal $8 \%$. Kemudian berdasarkan pengelompokan usia $\geq 70$ tahun kadar kolesterol total normal $8 \%$ dan abnormal 4\%, untuk HDL kolesterol normal 5\% dan abnormal 2\%, LDL kolesterol normal 2\% abnormal 6\% dan trigliserida diperoleh hasil persentase yang sama yaitu kadar normal 4\% dan abnormal 8\%.

Berdasarkan pengelompokan pada tabel 2 dapat dilihat hasil pemeriksaan kadar profil lipid pada 50 pasien berdasarkan kelompok usia yang mengalami PJK (tabel 2.2). Pada pasien berdasarkan kelompok usia $\leq 50$ tahun persentase kadar kolesterol total normal adalah 12\% dan abnormal 20\%, HDL kolesterol normal 
$18 \%$ dan abnormal 2\%, LDL kolesterol normal 6\% dan abnormal 20\%, kemudian trigliserida normal 22\% dan abnormal 6\%. Berdasarkan usia 51-60 tahun persentase kadar kolesterol total normal 6\% dan abnormal 26\%, HDL kolesterol normal 38\% dan abnormal 2\%, LDL kolesterol normal 4\% dan abnormal $48 \%$, untuk trigliserida normal 2\% dan abnormal 18\%. Pada usia 61-70 tahun diperoleh hasil persentase kadar kolesterol total normal 4\%, abnormal 10\% dan HDL kolesterol yaitu normal 24\% dan abnormal 0\%, LDL kolesterol normal $0 \%$ dan abnormal 26\%, lalu trigriserida normal 10\% dan abnormal 2\%. Kemudian berdasarkan pengelompokan usia $\geq 70$ tahun kadar kolesterol total normal $12 \%$ dan abnormal $8 \%$, untuk HDL kolesterol normal 6\% dan abnormal 10\%, LDL kolesterol normal 8\% abnormal 12\% dan trigliserida diperoleh hasil persentase yang sama yaitu kadar normal 22\% dan abnormal 8\%.

Tabel 3

Persentase hasil pemeriksaan Profil lipid pada 50 pasien yang mengalami Stroke dan 50 pasien PJK di RSUD Budhi Asih berdasarkan Obesitas.

6.1. Stroke

\begin{tabular}{ccccccccc}
\hline & \multicolumn{2}{c}{$\begin{array}{c}\text { Kolesterol Total } \\
(\mathrm{mg} / \mathrm{dL})\end{array}$} & \multicolumn{2}{c}{$\begin{array}{c}\text { HDL kolesterol } \\
(\mathrm{mg} / \mathrm{dL})\end{array}$} & \multicolumn{2}{c}{$\begin{array}{c}\text { LD kolesterol } \\
(\mathrm{mg} / \mathrm{dL})\end{array}$} & \multicolumn{2}{c}{$\begin{array}{c}\text { Trigliserida } \\
(\mathrm{mg} / \mathrm{dL})\end{array}$} \\
\cline { 2 - 8 } Faktor resiko & $\begin{array}{c}\text { Normal } \\
\mathrm{n}(\%)\end{array}$ & $\begin{array}{c}\text { Abnormal } \\
\mathrm{n}(\%)\end{array}$ & $\begin{array}{c}\text { Normal } \\
\mathrm{n}(\%)\end{array}$ & $\begin{array}{c}\text { Abnormal } \\
\mathrm{n}(\%)\end{array}$ & $\begin{array}{c}\text { Normal } \\
\mathrm{n}(\%)\end{array}$ & $\begin{array}{c}\text { Abnorma } \\
1 \mathrm{n}(\%)\end{array}$ & $\begin{array}{c}\text { Normal } \\
\mathrm{n}(\%)\end{array}$ & $\begin{array}{c}\text { Abnormal } \\
\mathrm{n}(\%)\end{array}$ \\
\hline $\begin{array}{c}\text { IMT }<27 \\
\text { Normal }\end{array}$ & $6(12)$ & $7(14)$ & $13(26)$ & $1(2)$ & $2(4)$ & $12(24)$ & $7(14)$ & $7(14)$ \\
\hline $\begin{array}{c}\text { IMT }>27.0 \\
\text { Obesitas }\end{array}$ & $16(32)$ & $21(42)$ & $32(64)$ & $4(8)$ & $8(16)$ & $28(56)$ & $27(54)$ & $9(18)$ \\
\hline Jumlah & $22(44)$ & $28(56)$ & $45(90)$ & $5(10)$ & $10(20)$ & $40(80)$ & $34(68)$ & $16(32)$ \\
\hline
\end{tabular}

6.2. PJK

\begin{tabular}{|c|c|c|c|c|c|c|c|c|}
\hline \multirow{2}{*}{ Faktor resiko } & \multicolumn{2}{|c|}{$\begin{array}{l}\text { Kolesterol Total } \\
(\mathrm{mg} / \mathrm{dL})\end{array}$} & \multicolumn{2}{|c|}{$\begin{array}{l}\text { HDL kolesterol } \\
(\mathrm{mg} / \mathrm{dL})\end{array}$} & \multicolumn{2}{|c|}{$\begin{array}{l}\text { LDL kolesterol } \\
(\mathrm{mg} / \mathrm{dL})\end{array}$} & \multicolumn{2}{|c|}{$\begin{array}{c}\text { Trigliserida } \\
(\mathrm{mg} / \mathrm{dL})\end{array}$} \\
\hline & $\begin{array}{c}\text { Normal } \\
\mathrm{n}(\%)\end{array}$ & $\begin{array}{c}\text { Abnormal } \\
\mathrm{n}(\%)\end{array}$ & $\begin{array}{c}\text { Normal } \\
\mathrm{n}(\%)\end{array}$ & $\begin{array}{c}\text { Abnormal } \\
\mathrm{n}(\%)\end{array}$ & $\begin{array}{c}\text { Normal } \\
\mathrm{n}(\%)\end{array}$ & $\begin{array}{c}\text { Abnorma } \\
\ln (\%)\end{array}$ & $\begin{array}{c}\text { Normal } \\
\mathrm{n}(\%)\end{array}$ & $\begin{array}{c}\text { Abnormal } \\
n(\%)\end{array}$ \\
\hline $\begin{array}{c}\text { IMT }<27 \\
\text { Normal }\end{array}$ & $14(28)$ & $21(42)$ & $33(66)$ & $2(4)$ & $8(16)$ & $28(56)$ & $23(46)$ & $11(22)$ \\
\hline $\begin{array}{c}\text { IMT }>27.0 \\
\text { Obesitas }\end{array}$ & $6(12)$ & $9(18)$ & $11(22)$ & $4(8)$ & $0(0)$ & $14(28)$ & $9(18)$ & $7(14)$ \\
\hline Jumlah & $20(40)$ & $30(60)$ & $44(88)$ & $6(12)$ & $8(16)$ & $42(84)$ & $32(64)$ & $18(36)$ \\
\hline
\end{tabular}

(Sumber: Data RSUD Budhi Asih tahun 2019).

Berdasarkan pengelompokan pada tabel 3 dapat dilihat hasil pemeriksaan kadar profil lipid pada 50 pasien berdasarkan kelompok obesitas yang mengalami stroke (tabel 3.1) Pada pasien berdasarkan kelompok IMT $<27$ persentase kadar kolesterol total normal adalah 12\% dan abnormal 14\%, HDL kolesterol normal 26\% dan abnormal 3\%, LDL kolesterol normal 4\% dan abnormal 24\%, kemudian trigliserida normal 14\% dan abnormal 14\%. Berdasarkan IMT > 27 persentase kadar kolesterol total normal 32\% dan 
abnormal 42\%, HDL kolesterol normal 64\% dan abnormal 8\%, LDL kolesterol normal 16\% dan abnormal $56 \%$, untuk trigliserida normal 54\% dan abnormal $8 \%$.

Berdasarkan pengelompokan pada tabel 3 dapat dilihat hasil pemeriksaan kadar profil lipid pada 50 pasien berdasarkan kelompok obesitas yang mengalami PJK (tabel 3.2) Pada pasien berdasarkan kelompok IMT $<27$ persentase kadar kolesterol total normal adalah 28\% dan abnormal 42\%, HDL kolesterol normal 66\% dan abnormal 4\%, LDL kolesterol normal 16\% dan abnormal 56\%, kemudian trigliserida normal 46\% dan abnormal 22\%. Berdasarkan IMT > 27 persentase kadar kolesterol total normal 12\% dan abnormal 18\%, HDL kolesterol normal 22\% dan abnormal 8\%, LDL kolesterol normal $0 \%$ dan abnormal 28\%, untuk trigliserida normal $18 \%$ dan abnormal 14\%.

Tabel 4

Persentase nilai rasio LDL/HDL pada 50 pasien yang mengalami Stroke dan 50 pasien PJK di RSUD Budhi Asih .

\begin{tabular}{ccc}
\hline \multirow{2}{*}{ Nilai Rasio } & \multicolumn{2}{c}{ Jumlah Pasien (persentase) } \\
\cline { 2 - 3 } & $\begin{array}{c}\text { Stroke } \\
\mathrm{n}(\%)\end{array}$ & $\begin{array}{c}\text { PJK } \\
\mathrm{n}(\%)\end{array}$ \\
\hline$<3,0$ & $36(72)$ & $31(62)$ \\
\hline $3,0-6,0$ & $14(28)$ & $19(38)$ \\
\hline Jumlah & $0(0)$ & $0(0)$ \\
\hline
\end{tabular}

. (Sumber : Data RSUD Budhi Asih, 2019)

Berdasarkan pengelompokan pada tabel 4 dapat dilihat hasil pemeriksaan kadar profil lipid pada 50 pasien berdasarkan kelompok nilai rasio LDL/HDL yang mengalami Stroke. Pada pasien berdasarkan nilai rasio $<3,0$ adalah 72\% (36 pasien), rasio 3,0 - 6,0 28\%(14 orang) dan, rasio $>6,0 \quad 0 \%$. Dan 50 pasien yang megalami PJK adalah nilai rasio $<3,0$ adalah 62\% (16 pasien), rasio 3,0 - 6,0 36\% (18 orang) dan, rasio $>$ $6,00 \%$.

Tabel 5

Distribusi rata-rata kadar profil lipid berdasarkan pasien yang mengalami Stroke dan PJK di RSUD Budhi Asih dengan menggunakan Spss.

Uji T Independens

\begin{tabular}{ccccc}
\hline Profil lipid & $\begin{array}{c}\text { Jenis } \\
\text { penyakit }\end{array}$ & $\begin{array}{c}\text { Rata-rata } \\
\text { kadar }\end{array}$ & $\begin{array}{c}\text { Standar } \\
\text { Deviasi }\end{array}$ & p-Value \\
\hline Kolesterol & Stroke & 210.4400 & 46.85721 & 0.303 \\
\hline HDL & PJK & 220.3600 & 49.01718 & \\
\hline LDL & Stroke & 49.7000 & 10.15442 & 0.745 \\
\hline PJK & 50.4000 & 11.31010 & \\
\hline Trigliserid & Stroke & 133.5000 & 39.35980 & 0.635 \\
\hline & PJK & 137.2200 & 38.87200 & 0.301 \\
\hline
\end{tabular}

.(Sumber : Data RSUD Budhi Asih, 2019) 
Menurut data pada tabel 5 nilai rata-rata dari kadar kolesterol pada stroke lebih kecil dari kadar PJK, kadar HDL pada stroke lebih kecil dari pada kadar PJK, Kadar LDL pada stroke lebih kecil dari kadar PJK, Dan kadar trigliserid pada stroke lebih kecil dari pada PJK.

Berdasarkan hasil persentase pada tabel 1 didapatkan kadar profil lipid abnormal tertinggi terdapat kadar LDL pada Stroke $80 \%$ dan PJK 84\%. Hal ini menunjukkan bahwa kadar LDL berpengaruh lebih besar terhadap stroke dan penyakit jantung koroner. Kolesterol dalam darah yang berlebihan dapat mengakibatkan penyempitan dan penyumbatan pembuluh darah yang kemudian dapat menyebabkan penyakit jantung. Kadar kolesterol normal adalah sekitar $200 \mathrm{mg} / \mathrm{dl}$, sedangkan kadar kolesterol LDL tidak melebihi angka $100 \mathrm{mg} / \mathrm{dl}$ (Fatma, 2010:12)

Berdasarkan persentase hasil pada tabel 2 dapat dilihat bahwa persentase terbanyak dari kadar profil lipid berdasarkan usia terjadi pada usia 51 - 60 tahun. Telah diketahui bahwa proses degeneratif pada penuaan dapat mengurangi efektivitas metabolisme lemak, yang menyebabkan kadar kolesterol meningkat seiring dengan bertambahnya usia (Jaagus et al, 2010).

Berdasarkan hasil persentase pada table 3 dapat dilihat berdasarkan persentase kadar lipid profil berdasarkan obesitas, di dapatkan faktor IMT > 27 pada Stroke kadar tertinggi LDL 56\%. Pada PJK kadar tertinggi trigliserid 28\%. Dan kadar trigliserid pada Stroke normal adalah 54\%, abnormal 18\%, pada PJK kadar trigliserid nomal 18\%, abnormal 14\%.Lemak yang masuk ke dalam pembuluh darah dapat menyebabkan penyempitan arteri (hipertensi), diabetes, penyakit gallbladder, stroke, dan jenis kanker tertentu (payudara dan endometrium) (Adul, 2009:10)

Berdasarkan hasil persentase pada tabel 4 didapatkan persentase lipid profil berdasarkan nilai rasio LDL/HDL dengan faktor risiko rendah dengan nilai rasio $<3,0$ pada Stroke adalah 72\%, dan PJK 62\%, dan pada nilai rasio LDL/HDL dengan faktor risiko sedang dengan nilai rasio 3,0-6,0 Stroke 28\%, dan PJK 38\%. Pemeriksaan LDL dan HDL kolesterol lebih banyak manfaatnya, jika menggunakan perbandingan (rasio) LDL dengan HDL. Rasio LDL/HDL lebih bermakna menggambarkan risiko penyakit jantung koroner (Cardio Risk Indeks=CRI). (Laboratorium Kimia Farma)

Hasil pengolahan data pada tabel 5 dengan SPSS Uji T Independens di dapatkan nilai p-value kadar kolesterol adalah 0.303 dengan ketentuan $p$-value $<0.005$, maka secara statistik ada perbedaan kadar kolesterol pada stroke dengan PJK. Nilai p-value Kadar HDL adalah 0.745 dengan ketentuan p-value $<0.005$, maka secara statistik ada perbedaan kadar HDL pada stroke dengan PJK. Pada kadar LDL pvalue adalah 0.635 dengan ketentuan $\mathrm{p}$-value $<0.005$, maka secara statistik ada perbedaan kadar LDL pada stroke dan PJK. Pada kadar Trigliserid p-value adalah 0.301 dengan ketentuan p-value $<0.005$, maka secara statistik ada perbedaan kadar Trigliserid pada stroke dengan PJK (Mann-Whitney, Spss Uji T Idependens) 
Peningkatan kadar profil lipid mungkin lebih dikarenakan makin tua usia seseorang kadar profil lipid cenderung makin tinggi karena diet yang tidak terkendali dan aktifitas fisik yang berkurang mengakibatkan tubuh makin gemuk dan beresiko mengalami hiperlipidemia.

Pada usia yang semakin tua, metabolisme akan semakin menurun dan aktifitas fisik juga semakin berkurang. Oleh karena itu, energi yang dibutuhkan tubuh juga lebih rendah. Dalam kondisi tubuh yang demikian, bila kualitas dan kuantitas asupan makanan tidak berubah saat usia tua maka akan terjadi kelebihan kalori yang diperlukan. Akhirnya tubuh mengubahnya menjadi timbunan lemak, sehingga teradilah kenaikan berat badan dan jika kondisi tidak terkontrol akan timbul penyakit, salah satu dampaknya yaitu hiperlipidemia.

\section{SIMPULAN}

Berdasarkan analisis hasil didapatkan kadar profil lipid abnormal tertinggi terdapat kadar LDL pada Stroke $80 \%$ dan PJK 84\%. Hal ini menunjukkan bahwa kadar LDL berpengaruh lebih besar terhadap stroke dan penyakit jantung koroner. Setelah melakukan analisa data dengan menggunakan Spss Uji T independens menurut stastistik adalah ada perberdaan terhadap profil lipid pada penderita penyakit stroke dan PJK pada RSUD Budhi Asih.

\section{UCAPAN TERIMA KASIH}

Penulis mengucapkan terima kasihh kepada Prodi D III Analis Kesehatan Universitas MH Thamrin berperan serta dalam penelitian ini.

\section{DAFTAR PUSTAKA}

1. Abdurrahman, N., Simposium Pendekatan Holistik Penyakit Kardiovaskular II, Edisi 1, Bagian Ilmu Penyakit Dalam FKUI, Jakarta, 2003.

2. Adam, J.M.F. Dislipidemia. Dalam Buku Ajar Ilmu Penyakit Dalam.Edisi Ke III, Jakarta, 2009

3. Ahmad H, Memerangi Diabetes Melalui Diet Golongan Darah dan Pola Makan Yang Benar, Yogyakarta, 2009

4. Aliah A, Kuswara F.F, Limoa RA, Wungsang. Gangguan Peredaran Darah Otak Dalam: Kapita Selekta Neurologi. Gajah Mada Univercity press, Yogyakarta, 2003

5. Askandar Tjokroprawiro, Dkk Buku Ajar Ilmu Penyakit Dalam, Edisi-2, Airlangga Univercity press, 2015

6. Fauziah, Y.N, Perbedaan Kadar Trigliserid pada Pederita Diabetes Militus Tipe 2 Terkontrol dan Diabetes Militus Tipe 2 tidak terkontrol Falkutas Kedokteran dan Ilmu kesehatan Universitas Muhammadiyah, Yogyakarta, 2012

7. Gofir, Abdul. 2009 .Evidance Base Medicine; Manajemen Stroke, Pustaka Cendikia Press, Yogyakarta 
8. Greestein,B.dan Wood, D.F., At a Glance SISTEM ENDOKRIN, Edisi kedua, Erlangga, Jakarta, 2010

9. Junaidi, Iskandar, STROKE, Waspadai Ancamannya. Yogyakarta, 2011

10. Kaplan, N.M., dan Stamler, J., Pencegahan Penyakit Jantung Koroner: Penatalaksanaan Praktis dari Faktor-Faktor Resiko, EGC, Jakarta, 1991

11. Kasron, Buku Ajar: Gangguan Sistem Kardiovaskuler, Nuha Medika, Yogyakarta, 2012

12. Kee, J.L., Pedoman Pemeriksaan Laboratorium \& Diagnostik, Edisi 6, Penerbit Buku Kedokteran EGC, Jakarta, 2007

13. Muir K.W. Stroke, Medical Progress, 37:235-9. 2010.

14. Oetomo, K.S., Pengendalian dan Pengobatan Obesitas, Universitas Brawijaya Press, Malang, 2011

15. Perhimpunan Dokter Spesialis Kardiovaskular Indonesia (PERKI), Pedoman Tatalaksana Dislipedemia, Jakarta, 2013

16. Perhimpunan Dokter Spesialis Kardiovaskular Indonesia (PERKI), Pedoman Tatalaksana Hipertensi pada penyakit Kardiovaskular, Jakarta, 2015

17. Perhimpunan Dokter spesialis Saraf (PERDOSSI), Pokdi Stroke Guideline Stroke, Pekan baru, 2011

18. Prakoso, R.A, AWAS KOLESTEROL! Panduan Hidup Sehat Bebas Kolesterol Jahat, Aulya Publishing, Yogyakarta, 2012

19. Pramono L.A. Dislipidemia, Medica Jurnal Kedokteran Indonesia. Edisi 7, Volume 35. 2009

20. Ridwan, Muhamad. Mengenal, Mencegah. Mengatasi Silent Killer Hipertensi. Semarang, 2013

21. Soeharto, I., Penyakit Jantung Koroner (PJK) dan Serangan Jantung, Edisi III, PT. Gramedia Pustaka Utama, Jakarta, 2004

22. Sudoyo, A.W. Buku Ajar Ilmu Penyakit Dalam Edisi 5. Jakarta, 2010

23. Supardan, Dr., Metabolisme Lemak, Laboratorium Biokimia FK Universitas Brawijaya, Malang, 2002

24. Young I, Rifai N. High-Sensitivity C-Reactive Protein and Cardiovascular Disease. Clinical Chemistry. 2009;55(2):201-2. 2. 